\title{
GWAROWE FORMY NAZWISK KOBIET W KOMUNIKACJI INTERNETOWEJ
}

Słow a tematyczne: nazwisko, formacje marytonimiczne, komunikacja internetowa, gwara, agresja językowa

\section{WPROWADZENIE}

Nazwisko w języku i kulturze ma szczególny status. Nie tylko (wraz z imieniem) identyfikuje nosiciela, ale jest jego dobrem osobistym i jako takie podlega ochronie prawnej. Pomimo że nazwisko w systemie antroponimicznym ustabilizowało się stosunkowo późno, szybko stało się wartością kulturową, istotnym elementem tożsamości w perspektywie indywidualnej i społecznej, nośnikiem wartości duchowych i moralnych (Kaleta, 1998, s. 153-167).

Nazwiska w oficjalnym obiegu występują w urzędowo zatwierdzonej formie i nie mogą być dowolnie zmieniane. W komunikacji potocznej niekiedy podlegają pewnym przeobrażeniom. Takie nieoficjalne formy nazwisk zwykle są tworzone od nazwisk z typowymi formantami nazwiskotwórczymi, a proces derywacji polega na odrzuceniu tych afiksów i odsłonięciu rdzenia, którym może być apelatyw, imię czy kompleks dźwiękowy bez szczególnej motywacji formalno-skojarzeniowej (Kosyl, 2001, s. 441). Możemy to zjawisko obserwować zarówno w przestrzeni medialnej, przykładowo w języku komentatorów sportowych (np. Hołek $<$ Hołowczyc, Kubi $<$ Kubiak, Lewy $<$ Lewandowski), jak i w codziennej komunikacji, np. stosunkowo częste przypadki derywacji wstecznej w języku młodzieży (np. Kowal $<$ Kowalski, Polak $<$ Polakowski, Żuraw $<$ Żurawski) ${ }^{1}$. Przekształcenia formalne nazwisk nie pozostają bez wpływu na ich wartość komunikacyjną i umożliwiają pełnienie różnych funkcji w tekście.

$\mathrm{W}$ artykule zostanie omówiony jeden typ przekształceń nazwisk w komunikacji internetowej, a mianowicie tworzenie nieoficjalnych form nazwisk

${ }^{1}$ Status form derywowanych od nazwisk bywa różnie interpretowany w literaturze przedmiotu. Niektórzy traktują je jako nieoficjalne formy nazwisk, inni jako przezwiska (Dunaj, 2017, s. 81). Tutaj opowiadamy się za pierwszym stanowiskiem. 
kobiet z wykorzystaniem wybranych gwarowych sufiksów marytonimicznych. Przedstawione zostaną także najważniejsze funkcje, jakie tego typu derywaty mogą pełnić w tekstach tworzonych przez użytkowników Internetu. Rozważania zostaną ograniczone do grupy nazwisk kobiet uczestniczących w życiu politycznym. Wybór onimów z tej grupy jest spowodowany tym, że dyskusje o polityce są częste w internetowej przestrzeni komunikacyjnej i właśnie tam możemy obserwować liczne modyfikacje formalne nazwisk. Tak nakreślona podstawa badań umożliwi poruszenie dwóch aspektów funkcjonowania nazw własnych, a mianowicie jak manifestuje się płeć w języku i jaką wartość komunikacyjną mają elementy wykorzystanych kodów gwarowych. Materiał egzemplifikacyjny został zaczerpnięty przede wszystkim z komentarzy internetowych zamieszczonych pod tekstami dziennikarskimi lub publicystycznymi odnoszącymi się do aktualnych wydarzeń politycznych czy społecznych, publikowanych na internetowych portalach informacyjnych czy w elektronicznych wydaniach czasopism. Wykorzystano także materiał z komentarzy zamieszczonych na portalach o innym profilu, na których rozwinęły się dyskusje dotyczące polityki (np. portale społecznościowe, sportowe, plotkarskie). Część materiału pozyskano z blogów publicystycznych. Analizowane wypowiedzi internautów pochodzą $\mathrm{z}$ lat 2010-20212.

\section{FORMACJE MARYTONIMICZNE W GWARACH}

W języku ogólnym do urabiania nazwisk odmężowskich służą dwa sufiksy: -owa i -ina, choć — jak twierdzi Maria M. Nowakowska: „urzędowo przyłączane są rzadko lub wcale”3, a w kontaktach nieoficjalnych ,formy żeńskie nazwisk tworzy się, jeśli w ogóle się to robi, przez dodanie sufiksu -owa do którychkolwiek nazwisk męskich o charakterze rzeczownikowym" (Nowakowska, 2016, s. 73-74).

Gwary w porównaniu z polszczyzną ogólną miały znacznie bardziej rozbudowany system tworzenia nazw marytonimicznych. Alfred Zaręba (1983, s. 508) wylicza następujące przyrostki, które w gwarach polskich mogą pełnić funkcję marytonimiczną: -ka, -owa (-owá), -ina (-iná), -a (-á), -ula, -icha, -ocha, -ania, -anka (-ánka), -ica, -na. Wraz z regresem gwar także i ten rozbudowany system tworzenia formacji odmężowskich został znacznie zredukowany. Już w latach 70.

2 Taki nieoczywisty przedział czasowy (11 lat) wynika z faktu, że w 2010 roku rozpoczęłam obserwację komunikacji internetowej pod kątem pojawiania się w niej elementów gwarowych i prowadzę te badania do dziś.

${ }^{3}$ Małgorzata Magda-Czekaj (2013, s. 161) zauważa, że „współcześnie używanie nazwisk $\mathrm{z}$ formantem -owa można jeszcze spotkać w pewnych środowiskach inteligenckich, które pielęgnują tradycyjną polszczyznę kulturalną. Prawie całkowicie nie spotyka się nazwisk na -inal-yna". 
XX wieku na ograniczanie się tego repertuaru sufiksów zarówno w języku ogólnym, jak i w gwarach zwrócił uwagę Mieczysław Karaś, wskazując, że w odniesieniu do nazw żon występuje układ: -owa w języku literackim, -owa/-ina/-ka/-ula w dialektach" (Karaś, 2017, s. 153). Czesław Kosyl do wspomnianego zestawu gwarowych formantów nazwiskotwórczych dodaje jeszcze -icha i zauważa, że niektóre z tych przyrostków mają określony zasięg występowania, a mianowicie -ula występuje w południowo-zachodniej części kraju, -icha zaś jest charakterystyczny dla wschodniej Polski (Kosyl, 2001, s. 441). Współcześnie w gwarach trzy sufiksy tworzą formacje odmężowskie o szerszym zasięgu: -owa, -ina, -ka, przy czym mogą być one zróżnicowane w zakresie fonetyki. W niektórych gwarach te sufiksy funkcjonują z utrwalonym kontynuantem dawnego $a$ pochylonego. Przykładowo Halina Kurek jako najczęściej występujące w gwarach okolic Dukli sufiksy marytonimiczne wymienia właśnie przyrostki: -ka, -owo oraz -ino (Kurek, 2019, s. 210). Badaczka zauważa, że w XX wieku:

Spośród nich dwu pierwszych używało się powszechnie, wskazując na powiązanie kobiety z mężem jako głową rodziny, natomiast sufiks -ino, charakterystyczny dla nazewnictwa najstarszej grupy kobiet, był już w zasadzie w fazie zaniku (Kurek, 2019, s. 210).

W środowisku wiejskim marytonimika są strukturami ustabilizowanymi, ma to swoje podłoże w stosunkach społecznych i rodzinnych właściwych polskiej wsi (Kurdyła, 2011, s. 154; Kurek, 2019, s. 204). W gwarach formy filiacyjne nazwisk $\mathrm{w}$ dalszym ciągu, nawet w sytuacji regresu terytorialnych odmian polszczyzny, są częściej stosowane niż w języku ogólnym, a jeden z sufiksów tworzących marytonimika charakteryzuje się nawet pewną ekspansywnością i wychodzi poza terytorialne odmiany polszczyzny. Sufiks $-k a$, bo o nim tu mowa, jak stwierdza Tomasz Kurdyła, ,przejmowany jest do języka ogólnopolskiego właśnie z języka wsi, za pośrednictwem tzw. nowej inteligencji” (Kurdyła, 2011, s. 155).

\section{NAZWISKA KOBIET POLITYKÓW Z SUFIKSAMI GWAROWYMI - EGZEMPLIFIKACJA MATERIAŁOWA}

Przekształcanie formy nazwisk $\mathrm{z}$ wykorzystaniem gwarowych cech morfologicznych rzadko jest zauważane przez badaczy języka. Aby udowodnić, że mamy do czynienia ze zjawiskiem wcale nie marginalnym, ale dobrze poświadczonym w tekstach internetowych, w tym miejscu prezentujemy dosyć obszerny wybór derywatów utworzonych od nazwisk kobiet polityków z wykorzystaniem trzech gwarowych sufiksów marytonimicznych: -owo $(<-o w a)$, -ino $(<-i n a)$ oraz $-k a^{4}$.

${ }^{4} \mathrm{O}$ formacjach z gwarowym sufiksem -icha używanych w odniesieniu do kobiet ze świata polityki, por. Kucharzyk (2019). 
W przypadku dwóch pierwszych w zasadzie uwzględniamy tylko postać z wygłosowym $o$, odzwierciedlającym typową właściwość wymowy gwarowej — realizację $a$ pochylonego jako $o$, pomijamy natomiast te zapisy, gdzie nie możemy być pewni, że przekształcenia nazwisk mają źródło w gwarach (jak już wspomniano, sufiksy -owa, -ina występowały, a niekiedy jeszcze występują w polszczyźnie ogólnej) .

-owo $(<-o w a)$ :

Kaj sie podziała Kopaczowo czy już we Kanadzie? (http://edukacja.swiatkobiety.pl).

Pamnientamy. Jak TVN namówił Begerowo do podsłuchiwania pisiorów wtedy było ok, tzw. kulisy polityki, wszystko dla dobra łobywateli, a jak:) (https://groups.google.com).

Lempartowo bedo bić i jej przyjaciółki (http://www.twigzu.com).

To nie zapraszajcie, kogo to obchodzi, zapraszajcie kogo chcecie. Adamowiczowo z Biedroniem zaproście albo Timermansa, albo Wałesa, albo tego co się zataczał, można by wymieniać godzinami (https://www.o2.pl).

Słuchej Markiela — wystarczy, że nam Wielgusowo podrzuciłaś, weź ty nie przeginaj, bo ludzie na twitterze i fejsie gadajo (https://twitter.com).

„My już mamy takiego protektora...” jest nieprecyzyjne... my mieliśmy a czy dalej będziemy mieli... już dzisiaj w nocy może się okazać gdy pięknemu Donaldowi puszczą hamulce... a Clintonowo się rozpłacze... (https://dyskusja.biz).

nie lubia PiS ani PO ale Piecha mo recht i oby Kluzikowo sie nie dostała... (https://dziennikzachodni.pl).

-ino $(<-$ ina $)$ :

Każdy komuch powinien kończyć jak Blidzino (http://biznes.onet.pl).

Szydlino może odtrąbić sukces. Była przecież burmistrzem w Brzeszczach. chyba że tam pojedzie i położy sie przed bramą, żeby zablokować przejęcie i zwolnienie części górników (http:// wyborcza.biz).

Ja osobiście mam taki pomysł, narazie kaczyński broni granic z macierewiczem, ale jak juz merkelino zacznie nam wpuszczać na siłe te bydełko to proponuje zrobić sciepe narodową, a gwarantuję że bedzie bardzo duzy odzew (http://eurosport.onet.pl).

${ }^{5}$ Ze względu na oszczędność miejsca, lokalizując cytat, ograniczamy się do podania adresu głównej witryny. Cytaty podane są zasadniczo z zachowaniem pisowni oryginalnej, usunięte zostały tylko nieliczne błędy literowe, które mogłyby wpłynąć na zrozumiałość cytatu. Omawiane antroponimy zostały wyróżnione kursywą dla łatwiejszego odnalezienia ich w tekście. 
Jak ma to kupuje, jest mega artystką i wolno jej kupować, dudzino żona dudy wydaje na ciuchy, na które zadnej szarej myszy nie byloby stać i nikt sie nie czepia a dudzino to tylko zona dudy czyli nikt (http://www.pudelek.pl).

Wczoraj w TVINFO produkowała się ta kobiecina Piterzyno. Z jej wywodów nic nie wynikało logicznego, wydawało się, że nie wiedziała po co przyszła do studia (http://wpolityce.pl).

U nas ten kult odnowił Sapkowski swoją tzw. trylogią husycką. I Ogórcyno, tylko tej książek nikt nie czyta, a Sapkowskiego i owszem (http://gabriel-maciejewski.szkolanawigatorow.pl).

Nachlał się i hormony mu buzowały, Kwasiorek był taki sam a niestety polacy na niego głosowali, taką jako polacy mamy naturę, zresztą europejczycy też co wyprawia Junker i to spływa po nich i po nas jak po kaczkach woda Tylko w sprawie Legionowa czego feministki zamilkły Gdzie Szajbuska, gdzie MYszka, gdzie Środzino, Płatkowo, Szczukowo dlaczego (https://www. stefczyk.info).

$-k a$ :

Merkelka może wyrzuty teraz robić Komorowi! Słusznie, bo może to ona chciała sobie Eneę wziąć! (http://aspiryna.salon24.pl).

Juz by zamknela jape Krasomowczyni Wassermanka (http://f.kafeteria.pl).

Do tej listy szwindli babci Hillary należy dodać „,reset z Rosją” i ogłoszoną 17 września 2009 r. rezygnację z budowy tarczy, gdy Clintonka była Sekretarzem Stanu. Oskarżenia Trumpa o prorosyjskość to są wręcz Himalaje hipokryzji (http://wpolityce.pl).

Jedynie Hubnerka ma minę adekwatną do wyniku. Rzekomo $72 \%$ narodu popiera unię, a zagłosowało $22,7 \%$, z tego $32,8 \%$ głosowało na kandydatów PO? Kto obliczy, ile wychodzi w rzeczywistości? (http://wiadomosci.wp.pl).

Bajzel mama lempartka, odrazajacy babol fuj (kzclip.com).

A Pani Ogórek, że wystartowała z listy SLD to wcale nie świadczy o jej lewicowości. Pamiętajmy jakie zgrzyty o nią były w partii skąd Miller ją wytrzasnął i dlaczego właśnie ją. A to już Senyszynka nawet jak i grubas Kalisz chcieli ja zastąpić. hahaha (https://kresy.pl).

Lubnauerka jak już wykończyła Nowośmieszną to może by się łaskawie wzięła za wykańczanie PIS. Chyba że jest podwójnym agentem albo co bardziej prawdopodobne ma to gdzieś. Kariera ważniejsza (https://www.gry-online.pl).

\section{WARTOŚĆ KOMUNIKACYJNA ZMODYFIKOWANYCH NAZWISK}

Pokazane wyżej przekształcenia nazwisk to przykład stylizacji językowej, rozumianej jako „świadome i celowe kształtowanie tekstu według obranego wzoru, nadanie mu zamierzonej postaci stylistycznej” (EJO 523). W tym wypadku jest to stylizacja gwarowa (dialektyzacja), czyli „używanie środków językowych 
charakterystycznych dla ludności wiejskiej” (EJO 523) ${ }^{6}$. Stylizacja językowa może dotyczyć wszystkich poziomów języka lub tylko wybranych jego podsystemów. Tutaj mamy do czynienia ze stylizacją fragmentaryczną, polegającą na wprowadzeniu do tekstu wybranych gwarowych formantów słowotwórczych ${ }^{7}$.

Tego rodzaju morfologiczne przekształcenia nazwisk służą ich ekspresywizacji ${ }^{8}$. Nazwiska w formie podstawowej, urzędowej są neutralne. Jakiekolwiek zmiany ich postaci powodują, że tracą neutralność i funkcjonują jako jednostki nacechowane (por. Dunaj, 2017, s. 80-81) ${ }^{9}$. Na forach, blogach i w innych przestrzeniach Internetu, gdzie dominuje potoczność i gdzie mamy do czynienia $\mathrm{z}$ wypowiedziami spontanicznymi, takie procesy są stosunkowo częste. Zwłaszcza dyskusje internetowe dotyczące polityki obfitują w ekspresywnie nacechowane antroponimy. Internauci, czując się anonimowymi użytkownikami sieci, niejednokrotnie odrzucają wszelkie konwencje obowiązujące w realnej komunikacji, sięgają po takie środki językowe, które w sytuacji rozmowy face to face byłyby nieakceptowalne. Skutkuje to zaostrzeniem tonu wypowiedzi, często prowadzi do tzw. hejtu, czyli do umieszczania nienawistnych, obraźliwych komentarzy, nasyconych agresją, pogardą, złością. Ponieważ hejt częściej jest skierowany ad personam niż ad rem wykorzystuje się w nim również antroponimy (Naruszewicz-Duchlińska, 2019, s. 101).

Funkcjonowanie nazw własnych w tekście mocno związane jest z kontekstem pozajęzykowym. Onim to nie tylko element języka pozostający w określonej relacji do innych jednostek języka, będący komponentem tekstu, ale także nazwa o konkretnej referencji. Onimy sygnujące znane postaci wywołują skojarzenia, które mogą stać się podstawą wtórnych użyć nazw.

Nazwiska kobiet polityków ukształtowane według gwarowych schematów tworzenia formacji marytonimicznych w komunikacji internetowej funkcjonują jako ekspresywizmy, które mogą pełnić różne funkcje ${ }^{10}$, a najważniejsze spośród nich to: wartościująca, perswazyjna, ludyczna oraz identyfikująca. Funkcje

${ }^{6}$ Trzeba za Aleksandrem Wilkoniem dodać, że stylizacja stanowi typ wypowiedzi wyraźnie ukierunkowanej, jej istotą jest odwołanie się do określonego wzorca językowego. Może ona mieć różny zakres i różne funkcje (Wilkoń, 1984). W naszym wypadku mamy do czynienia ze stylizacją zasadzającą się na przetworzeniu wzorca, posługiwaniu się jego elementami nieraz w sposób niezgodny z wyjściowym systemem. Jest to zabieg służący celom prześmiewczym, parodystycznym (por. Wilkoń, 1984).

${ }^{7}$ Należy zauważyć, że internauci zwykle nie znają zasad tworzenia formacji odmężowskich w języku ogólnym i całkowicie dowolnie przyłączają formanty marytonimiczne, na przykład tworzą derywaty z -ina od nazwisk zakończony na spółgłoskę (Merkelina $<$ Merkel, Witczyna $<$ Witek).

${ }^{8}$ O ekspresywizacji nazw własnych we współczesnych mediach polskich pisała Mariana Idzo (2015).

${ }_{9}$ Różne sposoby modyfikacji antroponimów identyfikujących osoby ze świata polityki przedstawili Barbara Kudra i Andrzej Kudra (2004, s. 97).

${ }^{10} \mathrm{Na}$ temat funkcji nazw własnych napisano już wiele, ale w dalszym ciągu onomastyka nie wypracowała klarownej typologii. Zwłaszcza w zakresie określania wtórnych funkcji onimów panuje duża dowolność terminologiczna. Przegląd stanowisk badaczy dotyczących tego zagadnienia zawiera artykuł Mariusza Rutkowskiego (2010). 
te najczęściej nie występują w izolacji, ale nakładają się na siebie, współistnieją, choć niekiedy jedna z nich może się wysuwać na pierwszy plan.

\subsection{Funkcja wartościująca}

Analizowane antroponimy - o czym już była mowa - mają charakter ekspresywny, a z ekspresją zawsze łączy się wartościowanie (Lubaś, 2003, s. 210). Użycie żeńskiej formy nazwiska, wskazującej na stan cywilny kobiety polityka, to językowa strategia deprecjacyjna (Kostro, Wróblewska-Pawlak, 2013, s. 157-161). Trzeba jednak podkreślić, że takie przekształcenia służą jednak przede wszystkim wyeksponowaniu żeńskości kobiety polityka, podkreślają jej płeć, a nie stan cywilny (w wypowiedziach niestylizowanych na gwarę bardzo często sufiks -owa przyłączany jest do nazwisk kobiet niezamężnych, np. Lempartowa, Wassermanowa $)^{11}$. Degradacyjny charakter mają już zmiany z wykorzystaniem formantów tworzących nazwiska żeńskie w polszczyźnie ogólnej. Uważa się, że ma tu wpływ posesywny charakter przyrostków: -owa, -ina w odniesieniu do żon czy -anka w odniesieniu do córek. Skala deprecjacji jest jeszcze większa, gdy przyłączany jest sufiks gwarowy. Po pierwsze następuje uwypuklenie cech żeńskich, takich jak wrażliwość, słabość, uczuciowość, które w sferze polityki nie są pożądane. Po drugie, onim konotuje wiejskość, społecznie przeważnie ujemnie wartościowaną, a na pewno negatywnie postrzeganą przez twórcę zmodyfikowanego nazwiska, por. np.:

Merkelowo nakłamała Trumpowi o umowie ramowej między Ukrainą a FR, w sprawie tranzytu, ale później przekonała Putina do jej zawarcia. Tak działają sankcje za NS2 (https://www. money.pl).

LUBNAUERKA to tak po prawdzie daleko nie odbiega od narcystycznych przypadłości owej śmiesznej i jakby nieco stukniętej GASIUCZKI-PIECHOWICZKI oraz komicznej WIELGUSKI (https://wydarzenia.interia.pl).

Żeby dostać trzy auta ochrony, wystarczy mieć niewyparzony pysk jak Szydlino z Przecieszyna. Baba ze wsi wyjdzie, ale małopolska wieś z baby nigdy nie wyjdzie (http://wyborcza.biz).

Ta nieszczęsna Jachirka prezentuje poziom całej PO. Już znacie powód czego nigdy nie wrócicie do władzy. Bo tacy z was politycy jak z tej maszkary aktorka (https://kolbuszowalokalnie.pl).

Tak przekształcone nazwiska są zatem nośnikiem wartościowania negatywnego i jest to wartościowanie bezpośrednie, widoczne już w strukturze wyrazu ${ }^{12}$.

${ }^{11}$ Por. stwierdzenie Aldony Skudrzykowej (1996, s. 20): „W polszczyźnie ogólnej w średnim i młodszym pokoleniu za jeszcze funkcjonujące można uznać jedynie formacje z przyrostkiem -owa. Funkcja tego przyrostka jest jednak daleka od pierwotnej: jest on głównie wykładnikiem żeńskości. Spostrzeżenie to potwierdzają liczne użycia nazwisk na -owa w odniesieniu do kobiet niezamężnych".

12 Wartościowanie bezpośrednie i pośrednie omówiła Jadwiga Puzynina (1992, s. 119-120). 
Posłużenie się w stosunku do kobiety polityka formacjami w rodzaju Kluzikowo, Szydlino, Wielguska, z gwarowymi formantami, to zawsze zabieg językowy mający na celu zdeprecjonowanie denotatu. Przekształcenie podstawowej postaci nazwiska, co więcej, nazwiska powszechnie znanego w całej wspólnocie komunikacyjnej, na postać z ujemnie waloryzującym formantem ,sprowadza ją do niższego poziomu prestiżowego lub też, rzadziej, do innego poziomu kontaktowego z ogólnego do lokalnego, co też ją dewaluuje" (Lubaś, 2012, s. 509).

Negatywne wartościowanie, widoczne już nawet w izolowanym antroponimie, może zostać jeszcze wzmocnione przez zastosowanie pewnych strategii komunikacyjnych. Jedną z nich jest umieszczenie takiego derywatu w strukturze formy adresatywnej. Nazwisko użyte w wołaczu, czasem wzbogacone o przydawkę, funkcjonuje jak wyzwisko, por::

KIDAWINO BIERZ KLUZIKA I SPADAJ STĄD (https://nowa.cozadzien.pl).

Szydlino dej sie zastrzelic za te cyganstwo sama nie wierzysz w to Co godosz ochydne babsko patrzec nie idzie Zaraz trzeba telewizor wylaczyc (http://wiadomosci.dziennik.pl).

Kempa zareagowała jak prawdziwa chrześcijanka, ba prawdziwa katoliczka! Pani Kempino dalej tak, przysporzy pani wyznawców (https://wiadomosci.dziennik.pl).

JESZCZE PARĘ DNI ZAKŁAMANA KOPACZKO I SKOŃCZYSZ JAK BRONEK — TWOJE KŁAMSTWA DOPROWADZAJĄ LUDZI DO TORSJI (https://wiadomosci.dziennik.pl).

Bezpośrednie zwroty do osób będących wyżej w hierarchii społecznej, niwelowanie dystansu pomiędzy autorem wypowiedzi a denotatem również mają wydźwięk wartościujący. Dochodzi wówczas do symbolicznego zrównania poziomów. Alina Naruszewicz-Duchlińska stwierdza:

Zwracanie się do ważnych i sławnych osób, które prawdopodobnie nigdy nie odczytają skierowanych do nich komentarzy, wyraża założenie, że można dyskutować z każdym jak równy z równym. Internetowi agresorzy negują standardowe poczucie hierarchiczności, charakterystyczne dla komunikacji bezpośredniej [...]. Hejter kreuje siebie na kogoś ponad tradycyjnym układem ról, ponad zasadami, ponad etyką i etykietą (Naruszewicz-Duchlińska, 2015, s. 133).

\subsection{Funkcja perswazyjna}

Wartościowanie jest $\mathrm{w}$ języku ściśle związane z perswazją. Internauta tak dobiera środki językowe, by przekonać odbiorców do swojego punktu widzenia. W ten sposób może na przykład wpływać na odbiór tekstu (artykułu, informacji), który komentuje. Zwykle liczba osób komentujących w sieci jest ogromna, a treści ważne czy kontrowersyjne bywają szeroko dyskutowane. Żeby komentarz został 
zauważony, powinien się czymś wyróżniać. Internauta musi zadbać o taki dobór środków językowych, który pozwoli zatrzymać uwagę czytelnika. Używanie zmodyfikowanych antroponimów identyfikujących powszechnie znane osoby dobrze służy temu celowi. Walor perswazyjny nazwisk poddanych dialektyzacji morfologicznej wynika z narzucających się asocjacji związanych ze wsią. Przekształcenie nazwisk kobiet polityków przez dodanie sufiksów -owo, -ino, - $k a$ sugeruje kierunek interpretacji, narzuca określony obraz działaczki. Kobieta polityk, opatrzona etykietą sytuującą ją w sferze wiejskości, zostaje zrównana z kobietami z niższej klasy społecznej, którym stereotypowo przypisuje się pewne ograniczenia, przede wszystkim intelektualne. Rezultatem tego jest osłabienie wagi stwierdzeń czy argumentów krytykowanej działaczki, negatywna ocena jej działań.

Podobnie jak w wypadku funkcji wartościującej, internauci, aby osiągnąć założony cel komunikacyjny — wpłynąć na poglądy odbiorców, narzucić swoją wizję świata, ośmieszyć poglądy i postawy innych osób — korzystają z różnych metod wzmacniania siły perswazji. Przykładowo, w poniższym fragmencie została wykorzystana metoda kontrastu. W dyskusji pojawiają się obok siebie elementy z różnych systemów językowych, a mianowicie z języka niemieckiego (Frau Lubnauer, Fraulein Wassermann) i z gwary (Lubnauerowo). Takie zestawienie budzi ciekawość odbiorców, a zapewne też samych uczestników dyskusji, którzy chętnie biorą udział w tej zabawie konwencjami i rozbudowują dialog o kolejne repliki deprecjonujące działaczki polityczne.

- To już prawie pewne, że po jesiennych wyborach samorządowych kropka przed eN zostanie wchłonięta przez PełO.

- A co na to Frau Lubnauer?

- A może spytasz Fraulein Wassermann? Lubnauer nigdy nie była przy korycie.

- Lubnauerowo se siedzi i kwiczy PO utraconym korycie!!!! (https://wiadomosci.dziennik.pl).

Formalne przekształcenia dokonywane w strukturze nazwisk informują o emocjach nadawcy w stosunku do denotatów, zwykle są to odczucia silnie negatywne, choć zdarzają się użycia o niższym ładunku negatywnych emocji, ale wyraźnie ironiczne, ośmieszające polityków, np.:

Fotyga powiedziała, że jeśli porówna swoją współpracę z prezydentem Lechem Kaczyńskim i Jarosławem Kaczyńskim jako premierem do jej „,ukochanej muzyki klasycznej”, to można powiedzieć, że tworzyli oni „taką grupę kameralną” jedyne takie trio — lesio, jaruś i fotyżka sam wdzięk, czar i wyczucie rytmu (https://forum.gazeta.pl).

Emocjonalizacja wypowiedzi to „narzędzie tworzenia wizerunku i narzędzie oddziaływania na bezpośrednich uczestników dyskursu i obserwującą publiczność" (Warchala, 2019, s. 274). We współczesnej komunikacji ujawnia się silny 
trend do prowokacji politycznej czy obyczajowej, czego wyrazem jest używanie elementów leksykalnych wyraziście nacechowanych, prowokujących, ośmieszających czy obrażających. Na taki dyskurs istnieje zapotrzebowanie społeczne (por. Warchala, 2019, s. 275). Deformacja nazwisk bazująca na stereotypach wsi i wiejskości z jednej strony doskonale wpisuje się w to zapotrzebowanie, stanowi element strategii komunikacyjnej o dużych walorach perswazyjnych, ale z drugiej strony — jest przejawem agresji językowej i mowy nienawiści, por. np.:

Myszke zostawiam dla kota Przewodniczacego. Krzywonosowo dla Petroniusza, z paroma kolezkami oczywizda. Thunowo jak łysiejaca rzepa dla Walezego na zmiane z kapo Szulcem. Frazyniug moze stac z wachlarzem. Ta roziczka to przechera nie do zdarcia! (http://blogmedia24.pl).

\subsection{Funkcja ludyczna}

Przekształcone antroponimy służą też realizacji funkcji ludycznej, choć jest to funkcja mniej istotna, drugoplanowa. Alina Naruszewicz-Duchlińska podkreśla: „Funkcja ludyczna jest wtórna i o ograniczonym zasięgu. Nazwa ma głównie obrażać, a przy okazji może śmieszyć swego kreatora i osoby podzielające jego punkt widzenia na daną osobę czy zjawisko" (Naruszewicz-Duchlińska, 2019, s. 107). Przykładów wypowiedzi internautów, w których realizuje się ta funkcja, jest zaskakująco wiele. Komizm bazujący na wykorzystaniu właściwości asocjacyjnych gwar jest szczególnie skuteczny w zakresie deprecjonowania osób czy ich działań, por. np.:

\footnotetext{
tobamowo by tu nijak nie pasowała bo corno [...] a łuna na fłotce to ta merkelowo cy ta sarkoziowo? (http://www.ostrowiecnr1.pl).

Coście tam Szydlino dzisiaj jęczeli? A dejcie se spokój. A bydlątka ochędorzone? A gnój posprzątany? (http://wiadomosci.onet.pl).

La Boga! Pewnikiem bedzie głosowoł na tom pyskatom i chamskom Pawłowiczowom! Łona tako samo jak tyn Stefon łot Sigeluf, ino mondruje a nic nie robi. [...] Tusku mo racje! Chopy z PiSa pchajom sie do jeuropejskiego koryta a tako Pawłowiczowo im nogie POdkłodo (http:// www.krosno24.pl).
}

Ludyczność onimów ma dużą wartość komunikacyjną. Wypowiedzi z komponentami, które mogą budzić wesołość, spotykają się z dużym odzewem, inspirują do kolejnych komentarzy. W tym wypadku jest to humor językowy, ewokuje on ocenę denotatów, ich działań, narzuca określony kierunek myślenia o wydarzeniach czy osobach, aktualizują się więc tu i funkcja wartościująca, i perswazyjna. 


\subsection{Funkcja identyfikująca}

Modyfikacja nazewniczych struktur z wykorzystaniem formantów gwarowej proweniencji może też pełnić funkcję identyfikującą ${ }^{13}$. Nawiązanie do dziedzictwa językowego spoza polszczyzny ogólnej wskazuje na określoną wspólnotę kulturową oraz ujawnia pewne informacje o nadawcach komunikatów. Tomasz Kurdyła pisze o funkcji identyfikującej formantów, „która na tym polega, że derywat $\mathrm{z}$ danym formantem charakteryzuje użytkownika, identyfikuje go jako członka danej grupy społecznej czy środowiskowej" (Kurdyła, 2003, s. 189). Również Alicja Nagórko wskazuje, że pewne typy formacji słowotwórczych ,pełnią rolę sygnałów identyfikacji grupowej" (Nagórko, 1998, s. 210). Wydaje się, że internauci, którzy uczynili komponentami swoich wypowiedzi derywaty typu Kopaczowo, Szydlino (z sufiksami -owo, -ino), znają antroponimiczny system gwarowy, mają określoną kompetencję w zakresie języka wsi, co może wskazywać na ich wiejskie pochodzenie. Nie można jednak wykluczyć, że te struktury zostały wykorzystane przez osoby sprawnie posługujące się językiem w różnych jego odmianach, aby zrealizować założone cele pragmatyczne lub tylko stylistycznie uatrakcyjnić wypowiedź. Na podstawie użycia derywatów z sufiksem - $k a$ trudniej wskazać związki z określonym środowiskiem, ponieważ odnazwiskowe derywaty z tym przyrostkiem bardzo się rozpowszechniły w komunikacji potocznej i współcześnie coraz rzadziej są odczuwane jako gwarowe.

\section{PODSUMOWANIE}

Nazwiska kobiet zajmujących się polityką, poddane dialektyzacji morfologicznej, stają się nazwami znaczącymi, ponieważ są obłożone „naddaną semantyką wynikającą z przekształcenia rzeczywistej nazwy według intencji nadawcy" (Lubaś, 2004, s. 258). Zmodyfikowane nazwisko uzewnętrznia stosunek internauty do osobowego denotatu, w tym wypadku kobiety polityka. Jest to forma wyszydzenia, obrażenia, poniżenia, zdeprecjonowania osoby. Funkcja wskazywania na osobę, identyfikowania jej, staje się drugorzędna. Najważniejsza jest wartość użytej formy nazwiska jako nośnika wartościowania, środka perswazji. Modyfikowanie antroponimów jest narzędziem walki z przeciwnikiem politycznym. Przekształcony antroponim to nazwa etykieta, która zastępuje neutralne, semantycznie puste właściwe nazwisko.

${ }^{13}$ Nie należy mylić tej funkcji z funkcją identyfikacyjną — podstawową funkcją onimów, której istota sprowadza się do wskazywania denotatu i odróżniania go od innych bez przekazywania treści znaczeniowej (por. Rutkowski, 2010, s. 54). 


\section{LITERATURA}

Dunaj, B. (2017). Funkcje nazw własnych [Functions of proper names]. Onomastica, 61(2), 77-89. EJO = Polański, K. (red.). (1993). Encyklopedia językoznawstwa ogólnego [Encyclopedia of General Linguistics]. Wrocław-Warszawa-Kraków: Zakład Narodowy im. Ossolińskich.

Idzo, M. (2015). Ekspresywizacja nazw własnych we współczesnych mediach polskich [Expressivization of proper names in current Polish media]. LingVaria, 20, 123-134.

Kaleta, Z. (1998). Nazwisko w kulturze polskiej [The Surname in the Polish Culture]. Warszawa: Slawistyczny Ośrodek Wydawniczy.

Karaś, M. (2017). Formanty lingwistyczne i onomastyczne [Linguistic and onomastic formants]. W: M. Karaś (red.), Ze studiów leksykologicznych i onomastycznych [Lexicological and Onomastic Studies] (s. 147-154). Kraków: Księgarnia Akademicka. [Przedruk z: Lingua Posnaniensis, 20, 1977, 19-25]

Kostro, M. i Wróblewska-Pawlak, K. (2013). Formy adresatywne jako środek jawnej i ukrytej deprecjacji kobiet polityków w polskim dyskursie polityczno-medialnym [Forms of address as a means of overt and covert depreciation of female politicians in political discourse in the Polish media]. Tekst i Dyskurs - Text und Diskurs, 6, 153-168.

Kosyl, C. (2001). Nazwy osobowe [Personal names]. W: J. Bartmiński (red.), Współczesny język polski [Contemporary Polish Language] (s. 431-445). Lublin: Wydawnictwo UMCS.

Kucharzyk, R. (2019). Formacje z sufiksem -icha/-ycha w wypowiedziach internautów [Formations with the -icha/-ycha suffix in Internet users' statements]. Język Polski, 99(4), 5-15.

Kudra, B. i Kudra, A. (2004). Między manipulacją a perswazją (o funkcjonowaniu antroponimów w tekście prasowym) [Between manipulation and persuasion (on the functioning of anthroponyms in the press)]. W: P. Krzyżanowski i P. Nowak (red.), Manipulacja w języku [Manipulation in Language] (s. 91-99). Lublin: Wydawnictwo UMCS.

Kurdyła, T. (2003). Pogranicza słowotwórstwa i leksykologii. Problemy interpretacyjne [On the border of word formation and lexicology. Interpretation problems]. Język Polski, 83, 187-193.

Kurdyła, T. (2011). Funkcje formantów rzeczownikowych w polszczyźnie ludowej (na przykładzie trzech wsi podkarpackich) [The Functions of the Noun Formants in Polish Dialects (as Exemplified by Three Villages in Podkarpacie)]. Kraków: Wydział Polonistyki UJ.

Kurek, H. (2019). Obraz społeczności wiejskiej Dukielszczyzny zakrzepły w nazwach kobiet zamężnych. Tradycja i zmiana [The image of rural community of the Dukla Region preserved in the names of married women. Tradition and change]. W: B. Grabka, R. Kucharzyk i A. Tyrpa (red.), Studia dialektologiczne [Dialectological Studies] (t. 5, s. 203-213). Kraków: Instytut Języka Polskiego PAN.

Lubaś, W. (2003). Polskie gadanie. Podstawowe cechy i funkcje potocznej odmiany polszczyzny [Polish Talk: Basic Features and Functions of Colloquial Polish]. Opole: Wydawnictwo UO.

Lubaś, W. (2004). Szczególna rola nazw własnych w funkcji perswazyjnej [The special role of proper names in the persuasive function]. Annales Academiae Paedagogicae Cracoviensis. Studia Linguistica, 2, 253-258.

Lubaś, W. (2012). Nazwy własne w funkcji perswazji politycznej [Proper names in the function of political persuasion]. W: I. Łuc i M. Pogłódek (red.), W komunikacyjnej przestrzeni nazw własnych i pospolitych. Ksiega jubileuszowa dedykowana Profesorowi Robertowi Mrózkowi [In the Communicative Space of Proper and Common Names. Festschrift Dedicated to Professor Robert Mrózek] (s. 497-511). Katowice: Wydawnictwo UŚ.

Magda-Czekaj, M. (2013). Nazwiska kobiet dawniej i dziś [Women's names in the past and today]. Onomastica, 57, 155-165.

Nagórko, A. (1998). Zarys gramatyki polskiej (ze stowotwórstwem) [An Outline of Polish Grammar (Including Word Formation)]. Warszawa: PWN. 
Naruszewicz-Duchlińska, A. (2015). Nienawiść w czasach internetu [Hatred in the Internet Age]. Gdynia: Novae Res.

Naruszewicz-Duchlińska, A. (2019). Antroponimy w hejcie [Anthroponyms in hate]. Poznańskie Studia Polonistyczne. Seria Językoznawcza, 26(1), 101-109. https://doi.org/10.14746/pspsj.2019.26.1.5

Nowakowska, M.M. (2016). Na co komu -owa (-ová/-ova/-eva), czyli o nazwiskach (i nie tylko) żeńskich w wybranych językach słowiańskich [What to whom: -owa (-ová/-ova/-eva), about the women's last names (and not only) in the selected Slavonic languages]. Rozprawy Komisji Językowej ŁTN, 62, 71-79.

Puzynina, J. (1992). Język wartości [Language of Values]. Warszawa: PWN.

Rutkowski, M. (2010). Problem funkcji nazw własnych w onomastyce. Przegląd stanowisk [The problem of functions of proper names in onomastics. Overview of the position]. Conversatoria Linguistica, 4, 54-65.

Skudrzykowa, A. (1996). Nazwiska żeńskie z przyrostkiem -owa we współczesnej polszczyźnie ogólnej [Female surnames with the suffix -owa in contemporary general Polish]. Język Polski, $76,17-23$.

Warchala, J. (2019). Formy perswazji [Forms of Persuasion]. Katowice: Wydawnictwo UŚ.

Wilkoń, A. (1984). Problemy stylizacji językowej w literaturze [Problems of linguistic stylization in literature]. Przeglad Humanistyczny, 3, 11-29.

Zaręba, A. (1983). Formy nazwisk żon i dzieci w dialektach języka polskiego [Forms of surnames of wives and children in Polish dialects]. W: A. Zaręba (red.), Pisma polonistyczne i slawistyczne [Polish and Slavic Writings] (s. 500-569). Warszawa-Kraków: PWN. [Przedruk z: Onomastica, 11,1966 , s. 320-344; 12, 1967, 232-275].

\section{SUMMARY}

\section{DIALECTAL FORMS OF WOMEN'S NAMES IN INTERNET COMMUNICATION}

Names in official circulation appear in an officially approved form and may not be freely changed. In informal communication they sometimes undergo certain transformations, which affects their communicative value. The paper analyses one type of name transformations in Internet communication, namely the creation of unofficial forms of women's surnames using selected dialect maritonymic suffixes.

The analysis was limited to the names of women participating in political life. The names of women politicians formed according to dialect patterns of maritonymic formation in Internet communication function as expressivisms that can perform various functions, the most important of which are the evaluative, persuasive, ludic and identifying ones.

Keyw ords: surname, maritonymic formations, Internet communication, dialect, verbal aggression 